\title{
The Baltic Sea Region: The Territory and Inner Structure
}

\author{
Andrey P. Klemeshev \\ Immanuel Kant Baltic Federal University, Russian Federation
}

\author{
Nikolay M. Mezhevich ${ }^{*}$ \\ Saint Petersburg State University, Russian Federation \\ *Corresponding Email: litovka@peterlink.ru
}

Gennady M. Fedorov

Immanuel Kant Baltic Federal University, Russian Federation

Doi:10.5901/mjss.2015.v6n6s7p212

\begin{abstract}
One of the consequences of globalization that is developing in the world is regionalization. Not only national, but also international regions are shaping up featuring different hierarchical levels: macro-, meso- and micro-regions. Among the most established regions is the Baltic Sea region, consolidating states (Sweden, Denmark, Finland, Lithuania, Latvia, and Estonia) and administrative units of the states situated on the seacoast (of Russia, Germany, and Poland). This is a coherent region united by economic, political, and social internal links, as well as by the common issue of conservation of the Baltic Sea nature. Within it, there can be distinguished parts that differ from one another by history, national and religious makeup, the level and structure of the economic development. The paper, on the basis of comparative statistical and factographic analysis, shows both the links uniting the Baltic Sea region in an integral whole, and its most considerable inner differences.
\end{abstract}

Keywords: Baltic Sea region, Baltic Sea states, regionalization, international region

\section{Introduction}

One of the results of globalization is an increasing regionalization. Both national regions (located within one country) are developing as well as international, consolidating different states and/or parts of states. The regions develop at different hierarchical levels: these can be macro-, meso- or micro-regions. Among those actively developing macro-regions is the Baltic Sea region. Water routes by the Baltic Sea since ancient times have united people living on its shores. The periods of cooperation and confrontation of the countries located in the Baltic have alternated with each other. Since the early 1990s, transborder cooperation has been actively developing here that furthers strengthening the internal links, making the Baltic Sea region an integral entity. Nevertheless, the differences between its parts are quire considerable, and progressive advances towards the integration occasionally come up against emerging problems, especially when the matter concerns the relationships between EU countries and Russia, NATO and Russia. There are also other considerable economic and socio-cultural differences within the region. The paper will deal with the composition of the Baltic Sea region and its inner structure, as seen by the Russian authors.

\section{The Composition of the Baltic Sea Region}

Nine states are located on the shores of the Baltic Sea region. In the order of the population decreasing, these include Russia, Germany, Poland, Sweden, Denmark, Finland, Lithuania, Latvia and Estonia. The Baltic Sea influences their development in different ways. It has a crucial impact on the development of, most notably, Baltic and Nordic countries situated in its coastal area. And for the countries of the Baltic Sea region that are larger in size and in the number of the population (Russia, Germany, and Poland) the Baltic Sea is only one of numerous chief geographic directions of their economic relations. The Baltic affects quite significantly only a part of their territories. The countries and parts of the countries situated on the Baltic Sea coast that crucially depend on it in their economic activities, notably in the development of their external-economic relations, make up the Baltic Sea region. 
Given that a region is understood not simply as an area identified by a researcher but a certain cohesiveness (a coherent region), it is only possible to call a certain body of states and/or their parts "a region" if it meets all or some of the following criteria:

1. The similarity of historical fates.

2. The cultural make-up characteristic of this group only (material and intellectual culture).

3. The geographic territorial integrity.

4. The presence of certain similar features in the economy.

5. Close economic, social and other internal links.

6. The collaboration in regional international organizations.

7. The regional identity developed to a varying degree.

The notion the Baltic Sea region gained a firm foothold in the international activities in the early 1990s, but until today there are different opinions regarding the geographical borders of the region. Managerial bodies interpret this notion on the basis of the practice of the increasingly developing cross-border cooperation.

Some believe that depending on the historical and political context, the Baltic Sea region can mean, at the least, seven political configurations not coincident in territory (NationMaster, 2013):

— the present Baltic States — Estonia, Latvia, Lithuania, and Kaliningrad exclave of Russia;

- East Prussia and historical lands of Livonia, Kurland and Estonia (Swedish Estonia and Russian Estonia);

- a geographical region mentioned above that was in some cases called by a borrowed word "Balticum" from the German Baltikum;

- the former Baltic province of imperial Russia, i.e. the lands mentioned in the previous two points supplemented by a part of Poland;

— the entire east side of the Baltic Sea, i.e. the areas mentioned above and Finland;

- the countries lying on the English trade route via the Baltic Sea, i.e. the territories named in the previous point plus the Scandinavian peninsula (Sweden and Norway); and and Russia.

- the countries of the Baltic Sea, i.e. the areas named in the previous point, supplemented by Denmark, Germany

Another fact can be added to the above-said: before World War II, Finland was considered as one of the four countries of the Baltic, and only in the 1950s it started being viewed as one of the Nordic countries (Lanko, 2007).

The provision of a physical and geographic rationale for the Baltic Sea region on the basis of the "basin" principle includes with it the territory of the drainage basin of the rivers running into the Baltic Sea (Figure 1). Then, the part of the North-West of the Russian Federation adjacent to the Baltic Sea should also be included in it - St. Petersburg, Pskov, Kaliningrad, the major part of Novgorod Oblast, part of Karelia, small territories of Arkhangelsk and Murmansk Oblasts, and also Tver Oblast belonging to the Central Russia. As regards the foreign states, the following are part of the Baltic Sea region: the Baltic States entirely (Lithuania, Latvia, and Estonia), practically entire Poland, the major part of Sweden and Finland, more than half of the territory of Denmark and almost half of Belarus, North-East Germany, small areas of the Ukraine, Czech Republic and Slovakia. This is the very composition that the Baltic Sea region appears in the international programme "Baltic University" initiated by Uppsala University (Sweden), which is comprised of over 200 higher education institutions.

For the purpose of spatial planning, the international programme "Vision and Strategies around the Baltic Sea" (VASAB) refers to the Baltic Sea region Denmark, Sweden, Norway, Finland, the Baltic States, Poland, Belarus, lands of Germany - Schleswig-Holstein, Mecklenburg - Vorpommern, Brandenburg, the cities of Berlin and Hamburg, and subjects of the Russian Federation - the city of St. Petersburg, Leningrad Oblast, Pskov Oblast, Novgorod Oblast, Murmansk Oblast, Kaliningrad Oblast and the Republic of Karelia.

An important element of formation of a system of international relations in the Baltic Sea region is the issues of economic cooperation and its foreign policy background. And in this respect, the factor of tradition also affects the development of our relations with the countries of the Baltic Sea. The cultural ties between the North-West of Russia and the Baltic States should be particularly noted. Their spatial scale was relatively small, but they developed in the region that became a political centre of Russia in the aftermath of Peter's I reign.

All the above-mentioned attributes of a region are characteristic of the territory named the Baltic Sea region by a number of researchers (Gutnik \& Klemeshev, 2006; Fedorov et al., 1997, 2012; Baltic... , 2006; Mezhevich, 2004; Mikhaylov \& Mikhaylova, 2014) who include the following in the Baltic Sea region: Denmark, Sweden, Finland, Baltic States, German lands of Mecklenburg - Vorpommern and Schleswig-Holstein, Polish Warmian-Masurian Voivodeship, Pomeranian Voivodeship and West Pomeranian Voivodeship, as well as the following subjects of the Russian Federation — the city of St. Petersburg, Leningrad Oblast, Pskov Oblast, Novgorod Oblast and Kaliningrad Oblast (Figure 2). We 
believe that this interpretation of the notion is well grounded since these very areas in their development are especially closely connected with the Baltic Sea.

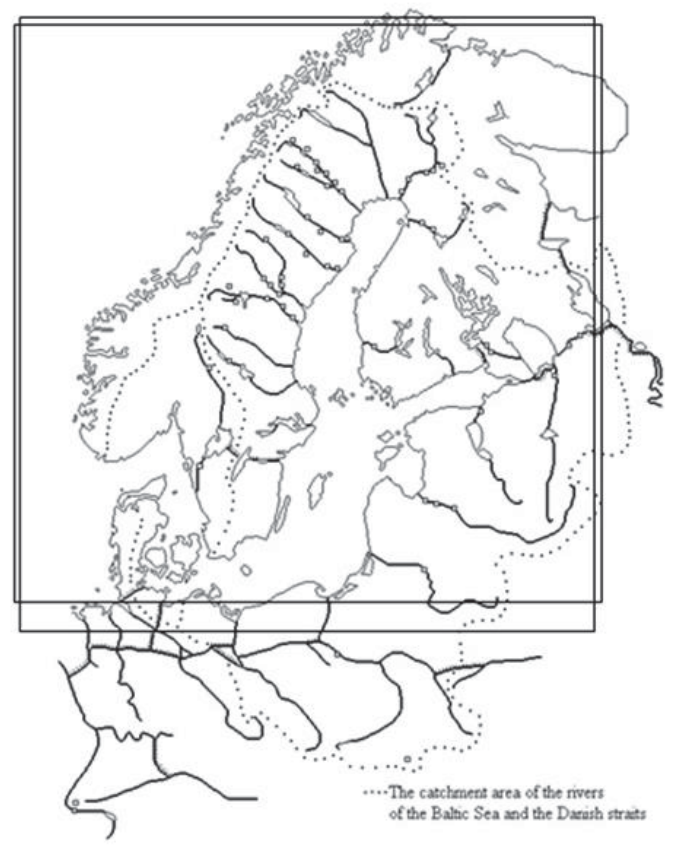

Figure 1. The Baltic Sea basin

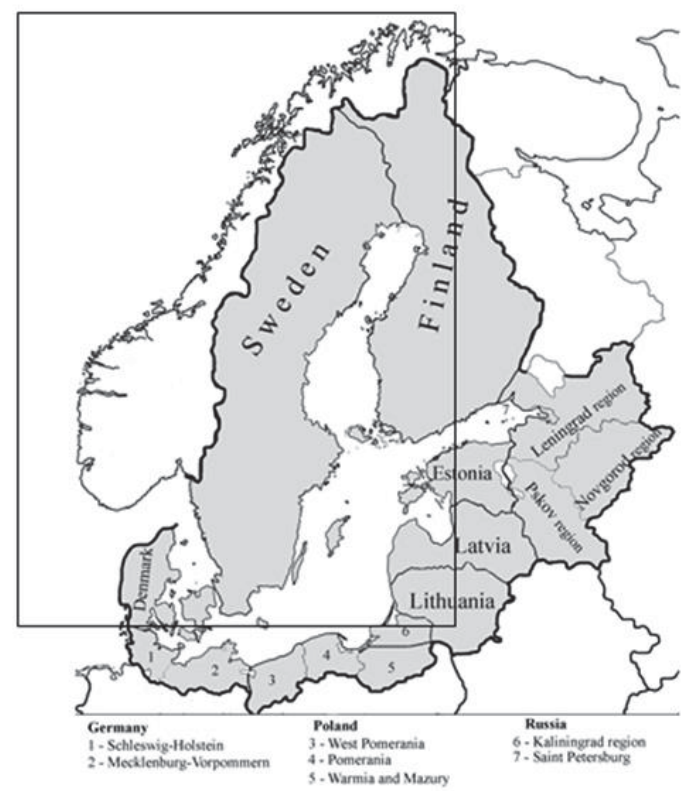

Figure 2. The Baltic Sea region 
In the Baltic Sea region, as viewed in this way, more than $46 \mathrm{ml}$ people reside on the area of 1321 thousand square kilometers. This amounts to less than $1 \%$ of the total area of land and less than $0.7 \%$ of the world's population. However, it accounts for $2 \%$ of the world gross domestic product. The production of GDP per capita here is on average almost 2.8 times higher than the world average rate, and the population density is 1.4 times lower (Fedorov et al., 2012).

What is significant is that the issue of a new character of regional identity was raised in the Baltic Sea region. This was best expressed by Peter Unwin, a former UK Ambassador to Denmark. He wrote: "The Baltic identity is an award that is worth having. It does not exclude the sense of belonging to Europe. It will not replace the national identity and love for the country. But it contains the simple truth that there is something special about the Baltic Sea region. This is the reality that has gone through both bad and good times. Its perseverance is another reason for being certain about the future of the Baltic Sea" (Mezhevich, 2000). This approach should not be perceived as exclusively borrowed from Europe. Academician, Director of the Institute of History of RAS raises an issue about the existence of a special Baltic civilization without giving an unambiguous answer to the question (Chubarian, 2015).

\section{The Inner Structure of the Baltic Sea Region}

The analysis of the inner structure of the Baltic Sea region from the perspective of the key social and scientific approaches allows for the conclusion that three countries are located on the Baltic Sea, which are too large for the region in geographic, economic and political terms. Firstly, this concerns Russia. In Russia's external-economic relations, the countries of the Baltic Sea region do not play a significant role: thus, in 2011 they accounted for only 14\% of Russia's goods turnover (Table 1). Russian policy documents in the sphere of foreign policy and, first of all, "Concept of the Foreign Policy of the Russian Federation" (Concept... , 2013), approved on February 12, 2013, are based on the global approach in spatial and substantive respect. It should also be noted that the Baltic Sea region is only implicitly mentioned in the document. "Russia is developing progressive practical collaboration with the countries of Northern Europe, including the implementation within multipartite bodies of joint projects on cooperation in the Barents/ Euro-Arctic region and in the Arctic Region on the whole taking into consideration the interests of indigenous people. Russia's participation in the collaboration within the Council of the Baltic Sea States is important. Russia is committed to further expose the project potential of the "Northern Dimension" and its partnerships as a platform of regional cooperation in the north of Europe".

It should be noted that three previous versions of the Concept of Foreign Policy gave a much more detailed account of the Baltic Sea region and its individual countries. The first post-Soviet version of 1993 gave almost as much consideration to the Baltic States (countries of the Baltic Sea region) as to building relationships with the USA. Within twenty years that passed between the enactment of the first and the latest Concepts of Foreign Policy the consideration was relatively reduced towards all the countries of the region including Germany. And the remote regions of Asia, Africa and the issues of Latin America are again among the priorities of Russian foreign policy.

Secondly, Germany has diverse interests at present. Its external relations are greatly diversified as concerns territories. The role of the countries of the Baltic Sea region in its external trade is even less than that for Russia (amounts to $11.5 \%$ of the foreign trade turnover).

A third quite a large country, occupying part of the Baltic Sea coast is Poland. In its foreign trade, the countries of the Baltic Sea region account for $41 \%$; within this figure more than $27 \%$ falls on trade with Germany and over $7 \%$ - with Russia, and less than $7 \%$ - with all the other countries of the Baltic Sea region.

Poland today is both a Baltic and a Central European state. However, the history of Poland testifies to the predominance of Central European land orientation of the external policy. Poland's geopolitical and geo-economic ambitions both in historical terms and within the context of the present day are considerably larger than the Baltic Sea and Eastern Europe. The country is lacking a conception of foreign affairs based on the stance that the interests of Poland are limited to Poland itself. The Polish historiography and political practice allow for the identification of two major paradigms of foreign policy - Piast and Jagiellonian. The former involves strong relations (both allied and confrontational) with Germany and relative inactivity towards the East. The latter is aimed at establishing a subordinate periphery in the East, control over Lithuania, Belarus, and Ukraine. Thus, Poland also in geopolitical terms "goes" far beyond the Baltic Sea region.

Consequently, the Baltic Sea region should include not the entire Russia, Poland and Germany, but their administrative-territorial units having immediate access to the Baltic Sea coast. 
Table 1. Share of countries of the Baltic Sea region in mutual turnover of commodities, 2011

\begin{tabular}{|c|c|c|c|c|c|c|c|c|c|c|}
\hline \multirow[b]{2}{*}{ Country } & \multicolumn{9}{|c|}{ Share in foreign trade turnover, $\%$} & \multirow{2}{*}{ 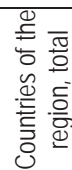 } \\
\hline & $\begin{array}{l}\frac{\pi}{N} \\
\frac{N}{2} \\
\frac{0}{\alpha}\end{array}$ & 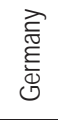 & $\begin{array}{l}\text { 믐 } \\
\frac{\pi}{0} \\
\frac{0}{0}\end{array}$ & 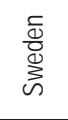 & 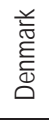 & 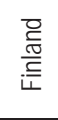 & 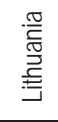 & : & 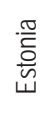 & \\
\hline Russia & & 7.1 & 2.4 & 1.0 & 0.2 & 1.8 & 1.0 & 0.3 & 0.2 & 14.0 \\
\hline Germany & 3.2 & & 3.8 & 1.8 & 1.5 & 0.8 & 0.2 & 0.1 & 0.1 & 11.5 \\
\hline Poland & 7.3 & 27.2 & & 2.6 & 1.7 & 0.8 & 0.9 & 0.4 & 0.3 & 41.1 \\
\hline Sweden & 3.3 & 13.8 & 2.7 & & 7.4 & 5.8 & 0.5 & 0.3 & 1.0 & 34.7 \\
\hline Denmark & 1.4 & 18.7 & 2.7 & 13.4 & & 2.1 & 0.5 & 0.3 & 0.3 & 39.3 \\
\hline Finland & 13.3 & 12.3 & 2.2 & 12.9 & 2.5 & 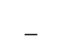 & 0.4 & 0.5 & 2.4 & 46.4 \\
\hline Lithuania & 24.6 & 10.2 & 8.3 & 3.4 & 2.3 & $\overline{1.6}$ & & 7.7 & 3.9 & 62.2 \\
\hline Latvia & 12.3 & 9.9 & 6.2 & 4.6 & 2.8 & 3.9 & 15.8 & & 9.5 & 65.1 \\
\hline Estonia & 8.9 & 8.3 & 4.1 & 13.2 & 2.2 & 15.9 & 6.5 & 8.2 & & 67.2 \\
\hline
\end{tabular}

Source: Fedorov et al., 2012

It is also worth mentioning an indisputable historical, socio-cultural and geographic unity of Nordic countries - Denmark, Sweden and Finland. Every issue of the official newsletter of the Nordic Council of Ministers starts with the following lead: "Norden" - a generic term of five Nordic countries - Denmark, Iceland, Norway, Finland and Sweden with autonomous territories: Faroe Islands and Greenland (Denmark) and Aland Islands (Finland). This approach is absolutely justified in economic terms. "The difference in scale" between the economy of Iceland and Sweden is not less than between Germany and Estonia, but the similarity of economic models and sectoral structure is significantly higher.

Lithuania, Latvia and Estonia have among themselves considerable socio-cultural and economic differences. Lithuanian and Latvian languages belong to the Balt language group, while Estonian language - to the Ugro-Finnic. Latvian and Estonian believers are primarily Protestants, while Lithuanians are Catholics. Nevertheless, owing to the commonness of the geopolitical position and, to a great extent, the similarity of historical fate, they even have a common name: the Baltic States. Their external economic relations are mainly orientated to the countries of the Baltic Sea region: they account for $60-70 \%$ of foreign trade of the Baltic countries.

Therefore, the following structure of the Baltic Sea region can be determined according to a number of formal signs:

1. Situated in the Baltic territories of Russia, Germany and Poland;

2. Countries of Northern Europe - Denmark, Sweden, and Finland; and

3. The Baltic States - Estonia, Latvia and Lithuania.

However, the typology based on the current political and economic situation in the countries of the Baltic Sea region differs considerably from that given above. Thus, even the earliest research papers, which considered the region within social sciences, tended to divide the Baltic Sea region into "east" and "west" parts. Notably, this approach can be seen in the work by U. Kivikari "Economic space of the Baltic Sea region" published in 1993. Later, the inconsistency of the socio-economic development of the Baltic Sea region and the multidirectionality of the countries' external economic and political relations made some authors divide the region into three parts. A first part was comprised of Nordic countries and the Baltic lands of Germany, a second - the Baltic States and the Northern regions of Poland, and a third - the North-West of Russia.

The established by the year 2013 territorial differences in the production of gross domestic product per capita (Figure 1) make it possible to distinguish the following parts of the Baltic Sea region:

- with a high level of GDP/GRP per capita:

- $\quad$ with a higher high level: the Nordic countries;

- $\quad$ with a lower high level: Schleswig-Holstein land (Germany);

- with a middle level of GDP/GRP per capita:

- $\quad$ with a higher middle level: St. Petersburg (RF), Mecklenburg-Vorpommern (FRG);

- $\quad$ with a lower middle level: Leningrad Oblast (RF), the Baltic States;

- with a low level of GDP/GRP per capita:

- $\quad$ with a higher low level: Kaliningrad and Novgorod Oblasts (RF), Warmian-Masurian Voivodeship (Poland);

- with a lower low level: Pskov Oblast (RF). 
And if we restrict ourselves to dividing the countries and administrative-territorial units of the Baltic Sea region only into two parts, the more economically developed can be considered the Nordic countries, the German lands and the city of St. Petersburg, while less developed are all the other subjects in question.

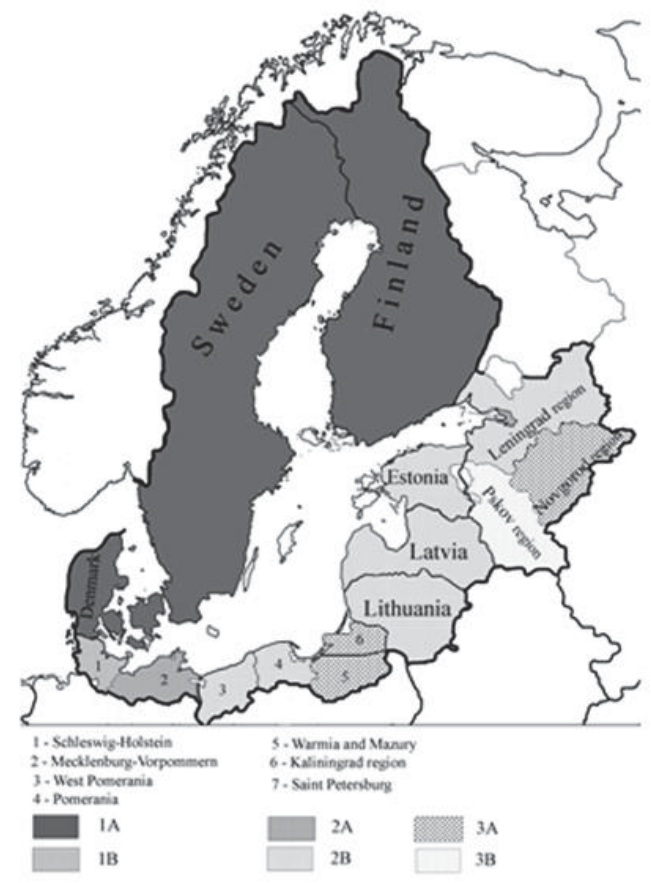

Figure 3. Distribution of the entities of the Baltic Sea region according to the amount of the Gross Domestic Product, Gross regional Product

(by the purchasing power parity) in per capita terms, Euro, 2013

1A: 30 - 35 thousand Euros

1B: 27 thousand Euros

2A: $20-25$ thousand Euros

2B: $15-20$ thousand Euros

3A: $13-15$ thousand Euros

3B: 9 thousand Euros

Sources: Eurostat, 2015; Federal... , 2015; The World..., 2015.

\section{The Ways of Strengthening the Internal Unity of the Baltic Sea Region}

Due to intense international transnational (between the states) and transborder (between the regions of states) cooperation, the Baltic Sea region has gone through the last twenty five years with fundamentally smaller economic and political losses than the other macro-regions of Europe, where transformations from socialism to capitalism were going on. A renowned Finnish scholar Urpo Kivikari (Kivikari, 2001) names the following unimpeachable achievements of economic and political development of the Baltic Sea region of the 1990s:

1. the issues of security in the region were urgent primarily at the level of soft security envisaging not a prospective readiness for a war, but a necessity to combat terrorism, drug trafficking and cyberthreats.

2. the region as a whole was characterized by a high level of intercultural communications and confessional tolerance. 
3. the level, the character, and the quality of development of democratic institutions in the Baltic Sea region as early as in the mid 1990s were determined as leading in the uniting Europe.

4. the economic indicators here testify to the reduction of intraregional differences in the levels and quality of living of the population.

The reasons of the relative success of the Baltic Sea region of Europe are sometimes also connected with the fact that the ending of the "cold war" resulted here in emerging a whole new kind of a territorial community - a transborder region including as actors both states and separate lands of states. In such a case, a most important component of a transborder region is the networks of numerous channels and relations between these actors. The number of subregional ties and networks connected with both national and regional interests is torpedoing the development of a new quality of regional cooperation. A fruitful collaboration of various institutions of the network cooperation was supposed to further the processes of transformation in this European sub-region. The coordinating role is played by the established in 1992 Council of the Baltic Sea States which now comprises, in addition to 9 countries which have access to the Baltic Sea, of Norway and Iceland, and also the Commission of the European Communities.

The establishment of the Baltic Sea region is accompanied by a relatively rapid development of the border cooperation here, by the formation of diverse spatial forms of transborder relations - Euroregions, associations, international intersectorial clusters. This promotes the integration of the region, especially of the areas which are parts of the European Union. But the major present internal differences in the Baltic Sea region still remain deep - these are the characteristic of the past decade and growing contradictions between the EU countries united economically and politically and members of the Eurasian Economic Union, between NATO states and Russia with its allies.

The Baltic Sea region has a considerable impact on the establishment of the present-day system of international relations in Europe and the world. While during the cold war the Baltic Sea was considered by many Europeans as a peripheral part of Europe, today the Baltic Sea region is being involved in global trade. The region is of special interest within the concept of the new Silk Route proposed by China. The actual refusal of the Baltic States of transit functions does not mean the region's loss of its geo-economic potential. Russia, Poland and Finland are seeking their niche within the new transport routes "Asia-Europe". The extension of international commerce, the growth of freight traffic, the involvement in the world economy of new regions and integration will help to overcome current economic problems. In the course of development and functioning of a system of international relations in the region, the consideration of traditions of cooperation and interaction between the North-West of Russia and Nordic countries is becoming increasingly important.

The issues of economic cooperation and its foreign policy background are becoming a significant element in the development of a system of international relations in the region. And in this the factor of tradition also affects the development of our relations with the countries of the Baltic Sea. A note should be made of cultural ties between the North-West of Russia and the Baltic States. Their territorial extent was quite small, but they were developing in the region that became a political centre of Russia in the aftermath of the reign of Peter I.

\section{Conclusion}

The above said allows for the conclusion of the significance of studying the Baltic Sea region issues in Russia. Under the established conditions, Russia is facing a difficult task: to formulate its political aims anew and to determine its interests in the sphere of national security not only at the global but also at the regional level. The determination of these interests is impossible without the adjustment of our stands and the stands of the Baltic States on the main characteristics of regional security.

Our main conclusion is that the Baltic Sea region due to its inner structure and historical prerequisites continues to possess a large potential for development. The task is to make use of this potential in the interests of development of all the countries of the region.

\section{References}

Chubarian, A.O. (2013). Does the Baltic civilization exist? [Online] Available: http://www.igh.ru/smi/224/ (August 19, 2015).

Concept of the Foreign Policy of the Russian Federation (2013). Approved by President of the Russian Federation V. Putin on February12, 2013. Official site of the Ministry of Foreign Affairs of the Russian Federation. [Online] Available: http://archive.mid. ru/brp_4.nsf/newsline/6D84DDEDEDBF7DA644257B160051BF7F (October 05, 2015).

Eurostat (2015). [Online] Available: http://ec.europa.eu/eurostat/data/database (October 01, 2015).

Federal State Statistics Service (2015). [Online] Available: http://www.gks.ru/ (October 01, 2015). 
Fedorov, G. M., Zverev, Yu. M., \& Korneevets, V. S. (1997). Russian exclave in the Baltic. Kaliningrad University. Kaliningrad.

Fedorov, G. M., Zverev, Yu. M., \& Korneevets, V. S. (2012). Russia in the Baltic: 1990 - 2012. Kaliningrad: IKBFU Publishing House.

Gutnik, A.P., \& Klemeshev, A.P. (ed.) (2006). The Baltic Sea region as a pole of economic integration of the North-West of the Russian Federation and the European Union. Kaliningrad: IKSUR Publishing House.

Kivikari, U. (1996). Economic space of the Baltic Sea region. Helsinki: Otava.

Kivikari, U. A (2001). Growth Triangle as an Application of the Baltic Sea Region. Policy Paper. Russian-European Centre for Economic Policy. [Online] Available: http://etela-suomi.fi/english/pdf/kivikari (October 05, 2015).

Lanko, D. A. (2007). The Baltic Sea region as the "North of Europe". Russia and the European Union: in search of an optimal model of rapprochement. SPb.

Mezhevich, N.M. (2004) The Baltic Sea region and Russia in the Baltic: characteristics of positioning. Megaregion - network confederation. [Online] Available: http://megaregion.narod.ru/stenogr_11.htm (October 02, 2015).

Mezhevich, N.M.(2000). International organisations of the Baltic Sea region: the main areas and the role in the development of a system of international relations. SPb.

Mikhaylov, A.S., \& Mikhaylova, A.A. (2014). Spatial and sectoral distribution of international clusters in the Baltic region. European Journal of Scientific Research, 121(2), 122-137.

NationMaster. [Online] Available: http://www.nationmaster.com/encyclopedia/Baltic-region (February 01, 2013)

The World Factbook. (2015) [Online] Available: https://www.cia.gov/library/publications/the-world-factbook/geos/rs.html (October 02, 2015) 